UDK: 371.3:159.928

Originalni naučni rad

Primljeno: 3.5.2018.

Odobreno za štampu:4.6.2018.

DOI: https://doi.org/10.46630/gped.1.2018.01

\title{
УЛОГА ДОДАТНЕ НАСТАВЕ У ПОДСТИЦАњУ И РАЗВОЈУ ДАРОВИТОСТИ
}

\author{
Марија Јовановић ${ }^{11}$, Тамара Вукић \\ Универзитет у Нишу, Филозофски факултет у Нишу, Департман за педагогију
}

\begin{abstract}
Ancmpaкm: Шаренолика понуда, како наставних тако и ваннаставних, активности у школи пружа могућност за развој даровитих ученика, подстицањем њихових потенцијала, склоности и способности и задовољавањем њихових специфичних потреба. У раду су приказани резултати истраживања чији је циљ био утврдити како наставници и родитељи даровитих ученика виде улогу додатне наставе у подстицању даровитости код ученика. Резултати су показали да поред изједначавања додатне наставе са припремом ученика за такмичења, наставници и родитељи препознају значајну улогу додатне наставе у остваривању индивидуализације у раду са даровитим ученицима. Наставници сматрају да додатна настава даровитим ученицима пружа знања и развија способности које није могуће стећи у редовној настави, пружа могућност да ученици задовоље своје потребе и интересовања али и испоље своју индивидуалност, доприноси сузбијању досаде и незаинтересованости које могу да се јаве код даровитих ученика у редовној настави. Иако имају изразито позитиван став о значају и улози додатне наставе у подстицању и развоју даровитих, наставници сматрају да даровитост није довољно подстицати само кроз додатну наставу.
\end{abstract}

Кључне речи: додатна настава, даровитост, ученици, наставници, родитељи.

\section{1. Додатна настава као облик унутрашњег диференцирања наставе}

Појам диференцијација означава стварање различитих услова и околности за извођење наставе, а према способностима и претходним знањима, искуствима и интересовањима ученика. То значи да се ученици издвајају у хомогене групе по сличним или истим обележјима (Lazarević, 2005) као што су: социопсихолошке одлике - интересовања, склоности, вредносне оријентације, моралне особине, социокултурно порекло, етнокултурне одлике; сазнајне одлике - знања, умења, навике, лично искуство; психолошке одлике - запажање, па-

\footnotetext{
${ }^{1}$ marija.jovanović@filfak.ni.ac.rs
} 
мћење, пажња, мишљење; физиолошке одлике - узраст, пол, конституционалне особине, здравствено стање, особености темперамента (Vilotijević i Vilotijević, 2016).

Диференцирање се односи на вредносно-неутрално разликовање ученика према узрасту, преко њиховог рангирања на основу достигнућа до издвајања оних ученика који из различитих разлога не могу да похађају редовну основну школу. У позитивном смислу, диференцирање може да значи стварање група ученика ради њиховог ефикаснијег напредовања. Диференцирање може да се односи на целокупан систем образовања и у том случају говоримо о школско-организационом нивоу или аспекту. Издвајају се и садржсани (различити нивои и профили образовања), као и дидактички (структуирање процеса учења за различите категорије ученика у некој сталној или провременој групи за учење) аспект (Đorđević, 1981). Дидактички аспект се односи на диференцирање у настави што подразумева усклађивање наставног процеса са психофизичким одликама појединих ученика. У диференцираној настави се води рачуна о индивидуалним разликама између ученика (Vilotijević, 1999), ученик је активнији и комуникативнији чиме превазилази недостатке фронталне наставе у којој има објекатску позицију. Диференцирана настава омогућује ученику упознавање својих могућности и граница и откривању специјалних способности код појединаца (Milinković, 2014).

У најширем смислу, диференцијација се дели на спољну и унутрашњу. Спољна диференцијација значи да се ученици групишу (у хомогене разреде или групе) на основу способности, знања или неких других одлика. Међутим, ово може да проузрокује озбиљне проблеме: при формирању одељења састављених од ученика тзв. одликаша, остала одељења остају без изразито способних ученика, а наставни процес остаје без изазовних тренутака, бриљантних одговора, занимљивих питања; оваква одељења окупљају преамбициозне, нарцисоидне личности пуне себе, болесно осетљиве на тешкоће у односима са другим ученицима, а на мање способне ученике се гледа иронично и потцењивачки; при формирању одељења према интересовањима ученика долази до једностраног развоја; диференцијацијом се успорава развој адаптационих механизама личности с обзиром на то да се наставни процес прилагођава ученику, а не обрнуто. Због свега наведеног, у пракси се избегава формирање хомогених одељења, али се диференцијација према способностима реализује у случајевима изразито талентованих ученика за поједине области за које се чак формирају и посебне школе (Vilotijević i Vilotijević, 2016). Унутрашња диференцијација се примењује у оквиру редовне наставе редовних разреда. Може бити примењена у свакој наставној ситуацији, а подразумева да наставник ученицима поставља различите захтеве у складу

са њиховим способностима (Đorđević, 1981; Vilotijević, 1999). Одељења остају хетерогена (Lazarević, 2005), односно чине их ученици који се разликују по способностима, претходним знањима и др. одликама, а поштовање ових различитости се остварује структурисањем садржаја, захтева и задатака (Vilotijević i Vilotijević, 2016). 
Као један од облика унутрашњег диференцирања наставе у пракси нашег образовног система јавља се додатна настава (Vilotijević, 1999) која подразумева хомогено груписање ученика сличних способности, односно ученика који поседују одређене потенцијале даровитости (Muratović i Musić, 2017). Реч је о факултативној ваннаставној активности која се организује за ученике изразито високих способности када је реч о одређеним школским активностима и предметима. Њих одликују особине попут дивергентног мишљења, радозналости, интересовања, мотивације и сл. које су израженије него код њихових вршњака. Такви ученици показују склоности, способности и интересовања за одређене научне и уметничке дисциплине или подручја (Hebib i Spasenović, 2011) и остварују високе резултате у појединим областима (Janković i Rodić, 2007).

\section{2. Обогаћивање редовног програма путем додатне наставе}

Додатна настава је намењена ученицима који су способни и вољни да прошире и продубе своје образовање, односно образовање које нуди редовна настава (Bakovljev, 1998), што не значи просто повећање и проширивање знања, већ његово продубљивање у ширем смислу, сагледавање узрочно-последичних веза и одноca, увиђање односа међу стварима и појавама, трагање за узроцима, проналажење нових и другачијих решења (Đorđević, 1981; Karijašević, 2013). Истовремено са продубљивањем знања, остварује се развој ученика у складу са индивидуалним могућностима и потребама (Hebib i Spasenović, 2011), односно остварује се основни смисао додатне наставе - подстицање развоја способности даровитих ученика у складу са њиховим потребама и интересовањима (Miljanović i Topić, 2010).

Осим њене заснованости на принципу диференцијације, додатна настава се организује и на принципу индивидуализације наставног рада (Hebib i Spasenović, 2011). Принцип индивидуализације захтева да се настава диференцира толико да се задовоље разлике међу ученицима у психофизичком развоју и могућностима, интересовањима, темпу рада, искуству (Vilotijević, 1999), склоностима, потребама, жељама, обавештености, способностима и особинама памћења, начинима реаговања (Marković, 2005), мотивацији, ставовима, темпераменту, карактеру, достигнућима - нивоу претходних знања и др. (Lazarević, 2005).

Остваривању овог принципа у додатној настави доприноси то што се програм рада креира кроз договор између ученика и наставника, приликом чега се узимају у обзир жеље и интересовања самог ученика (Vilotijević, 1999). То значи да програм додатне наставе није строго прописан што од наставника захтева доста креативности и маштовитости како би могао да заинтересује ученике и да прилагоди различите садржаје ьиховим интересима (Muratović i Musić, 2017). Додатна настава се реализује на основу програма редовне наставе. Тематски оквир се не проширује, али се градиво продубљује, а захтеви који се постављају пред ученике су знатно сложенији. Није неопходно утврђивати детаљне и дугорочне програме. Од наставника се захтева да рад у додатној наста- 
ви учини занимљивијим, динамичним, а то се може постићи избором задатака, коришћењем разноврсних поступака и медија (Vilotijević, 1999). Његова улога је у педагошком вођењу ученика: подстицању, помагању у самосталном раду, давању савета, упутстава, подршке и сл. Успешан рад са даровитим ученицима захтева: адекватан избор садржаја, проблема и питања из одговарајућих области, а који пружају могућности за интензивнији и продубљенији рад; избор метода, поступака, објеката, средстава, извора и сл.; различите видове груписања ученика за рад (индивидуални, рад у пару, групни рад); слободно одлучивање за избор садржаја, подручја и начина рада (Đorđević, 1981).

За додатну наставу је карактеристичан индивидуални облик рада, подстицање самосталности, иницијативности и слободе у коришћењу извора знања и видова вежби за усавршавање вештина и способности (Janković i Rodić, 2007). Вилотијевић (1999) истиче да је за додатну наставу погодан и групни рад, док је фронтални мање погодан. Он препоручује да се у раду користи решавање проблема, учење путем открића и други поступци којима се ученик мисаоно активира, јер додатна настава по природи подразумева постављање високих захтева. Поред тога, у додатној настави се развија активно и самостално критичко и стваралачко мишљење ученика и креативност. Ученик је максимално активиран у процесу сазнавања и активно учествује у процесу прераде информација (Đorđević, 1981).

\section{3. Даровити ученици у додатној настави}

Савремени систем образовања захтева школу „која пружа смисао заједничком суживоту бројних ,различитости“, која такве вредности и норме поставља као узор и чини их обавезнима, стварајући животни и искуствени простор за „добро осећање“ свих у њој“ (Stanojević, 2011). Сходно оваквом приступу Аџић (2011) указује на неопходност изградње индивидуалног програма за сваког даровитог ученика наводећи да је за идентификовање даровитих важна сарадња учитеља и наставника, с обзиром на то да је учитељ имао више времена и прилика да упозна сваког ученика, његове склоности, способности, могућности, па тако и његову даровитост. Сарадњу је потребно оријентисати ка унутарпредметном и међупредметном повезивању, ка интеграцији садржаја за које су даровити ученици заинтересовани, ка пројектима и сл. Он даље истиче како се најбољи резултати у раду са даровитим ученицима могу уочити у менторској настави, јер се даровитом ученику посвећује знатно више времена које није ограничено. Најчешћи начини рада су изванучионичка настава и рад на пројектима чије се временско трајање, такође, може прилагодити интересовањима ученика. Додатна настава и ваннаставни садржаји, организани у складу са наведеним или сличним начелима у раду са даровитим ученицима, су значајни у повезивању целокупног васпитно-образовног рада са овим ученицима.

Избору ученика који ће похађати додатну наставу потребно је посветити доста пажње. Одлична оцена из неког предмета не мора бити препорука за додатну 
наставу. У додатну наставу не би требало укључивати ученике који постижу одличан успех захваљујући изграђеним радним навикама, труду, а не захваљујући склоностима и способностима. Таленат ученика у неком предмету може да се утврди пажљивим праћењем од стране наставника, а уз помоћ родитеља, других наставника, педагога, психолога. У ту сврху се примењују разговори, тестови и др. инструменти, али даровитост се препознаје и кроз нпр. писмене саставе и др. видове запажања. Онда када се утврди да је ученик надарен за одређену област или предмет, као и да показује интересовање за исту, онда се закључује да му је потребна додатна настава како би даље развијао своју даровитост (Vilotijević, 1999). Након што се ученику укаже на његов потенцијал, потребно је дозволити му да слободно, заједно са родитељима одлучи да ли ће похађати додатну наставу или не. Ово значи да би укључивање ученика у додатну наставу морало да буде добровољно (Muratović i Musić, 2017). Не препоручује се да ученици похађају додатну наставу из више предмета, јер би то могло да их преоптерети. Додатну наставу је потребно организовати из предмета за који ученик има највише смисла јер је њен циљ да се код ученика брже развијају стваралачке способности и склоности, као и интересовања управо из таквих предмета (Vilotijević, 1999).

\section{4. Методолошки оквир истраживања}

Циљ истраживања усмерен је на утврђивање ставова наставника и родитеља даровитих ученика о улози додатне наставе у подстицању и развоју даровитости. Коришћена је дескриптивна метода и технике скалирања и анкетирања. У истраживању је учествовало 104 наставника и 30 родитеља даровитих ученика. Структура узорка у односу на истраживањем третиране варијабле представљена је у табели 1. Одговори наставника су обрађени у статистичком прогаму SPSS, док су одговори родитеља обрађени квалитативним путем. У односу на третиране варијабле, у раду су презентоване само тврдње код којих је утврђено постојање статистички значајне разлике.

Табела 1. Структура узорка

\begin{tabular}{lcclcc}
\hline \multicolumn{2}{c}{ Наставници } & \multicolumn{5}{c}{ Родитељи } \\
\hline Школа & $\mathrm{N}$ & $\%$ & Ниво образовања родитеља & $\mathrm{N}$ & $\%$ \\
Основна школа & 46 & 44,2 & Основна школа & 4 & 13,3 \\
Средња школа & 58 & 55,8 & Средња школа & 9 & 30 \\
Укупно & 104 & 100 & Виша/висока школа/факултет & 17 & 56,7 \\
& & & Укупно & 30 & 100 \\
Научна област & $\mathrm{N}$ & $\%$ & Ниво школовања деце & $\mathrm{N}$ & $\%$ \\
Природне науке & 56 & 53,8 & Основна школа & 9 & 30 \\
Друштвене науке & 48 & 46,2 & Средња школа & 21 & 70 \\
Укупно & 104 & 100 & Укупно & 30 & 100 \\
\hline
\end{tabular}


Као што се из Табеле 1 може видети, узорком је обухваћено 55,8 \% наставника средњих школа и 44,2\% наставника основних школа. Нешто већи број њих су наставници предмета који припадају природним наукама $(53,8 \%$ наспрам 46,2\%). Међу испитаним родитељима бројнији су родитељи са високом стручном спремом (56,7\%) и родитељи ученика средњих школа $(70 \%)$. Већи број родитеља ученика средњих школа је обезбеђен захваљући постојању специјалних одељења за талентоване ученике у средњим школа (талентовани математичари, физичари, информатичари).

\section{5. Резултати истраживања и дискусија}

Рад са даровитим ученицима у школској средини најчешће се остварује путем додатне наставе која се може успешно користити за задовољавање индивидуалних потреба даровитих, с обзиром на то да им пружа могућност да раде темпом који им одговара, на оном нивоу сложености који је примерен њиховим могућностима, као и да се баве садржајима који их интересују. У наставку су приказани ставови наставника, а потом и родитеља, о улози додатне наставе у раду са даровитим ученицима.

\section{1. Улога додатне наставе у раду са даровитим ученицима из угла наставника}

У остваривању додатне наставе улога наставника је незаменљива. Као планер, дијагностичар, организатор, реализатор, усмеривач, саветодавац, руководилац и модератор додатне наставе, наставник квалитетом васпитно-образовног рада обезбеђује успех њеног извођења. Из тога разлога ставови наставника могу представљати значајне информације о непосредној пракси додатне наставе и указати на потребе за њеним мењањем и унапређивањем.

Табела 2. Улога додатне наставе у раду са даровитим ученицима из угла наставника

\begin{tabular}{|c|c|c|c|c|c|c|c|c|c|c|c|c|}
\hline & \multicolumn{2}{|c|}{$\begin{array}{l}\text { Уопште } \\
\text { се не } \\
\text { слажем }\end{array}$} & \multicolumn{2}{|c|}{$\begin{array}{c}\text { Не слажем } \\
\text { се }\end{array}$} & \multicolumn{2}{|c|}{$\begin{array}{c}\text { Нити се } \\
\text { слажем, } \\
\text { нити се не } \\
\text { слажем } \\
\end{array}$} & \multicolumn{2}{|c|}{ Слажем се } & \multicolumn{2}{|c|}{$\begin{array}{c}\text { y } \\
\text { потпуности } \\
\text { се слажем }\end{array}$} & \multirow[t]{2}{*}{ M } & \multirow[t]{2}{*}{ SD } \\
\hline & $\mathrm{N}$ & $\%$ & $\mathrm{~N}$ & $\%$ & $\mathrm{~N}$ & $\%$ & $\mathrm{~N}$ & $\%$ & $\mathrm{~N}$ & $\%$ & & \\
\hline $\begin{array}{l}\text { У раду са даровитим } \\
\text { ученицима потребно } \\
\text { је примењивати } \\
\text { додатну наставу у } \\
\text { циљу подстицања }\end{array}$ & 1 & 1 & - & - & 6 & 5,8 & 33 & 31,7 & 64 & 61,5 & 4,528 & 0,696 \\
\hline
\end{tabular}


Додатна настава није неопходна у раду са даровитим ученицима, јер се њихова 25 даровитост успешно може подстицати у редовној настави Припрема ученика за такмичење је најважнији задатак додатне наставе Додатна настава даровитим ученицима пружа знања и развија способности које није могуће стећи у редовној настави Додатна настава доприноси сузбијењу досаде и незаинтересованости које могу да се јаве код даровитих ученика у редовној настави За подстицање даровитости, уместо додатне наставе, боље је примењивати акцелерацију или груписање ученика према способностима У додатној настави се могу задовољити потребе и интересовања даровитих ученика, што није могуће остварити у редовној настави

У додатној настави даровити ученици имају могућност да изразе своје склоности и способности и да даље развијају своју даровитост, што није могуће у редовној настави

Потенцијал даровитих ученика се може испољити тек у додатној настави Даровитост није довољно подстицати само кроз додатну $\begin{array}{llllllllllll}2 & 1,9 & 3 & 2,9 & 21 & 20,2 & 56 & 53,8 & 22 & 21,2 & 3,894 & 0,385\end{array}$ $\begin{array}{llllllllllll}3 & 2,9 & 9 & 8,7 & 26 & 25 & 44 & 42,3 & 22 & 21,2 & 3,702 & 0,994\end{array}$

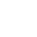
$2,9-14 \quad 13$

$\begin{array}{llllllllllll}1 & 1 & 3 & 2,9 & 26 & 25 & 57 & 54,8 & 17 & 16,3 & 3,827 & 0,768\end{array}$


На основу истраживања ставова наставника који су представљени у Табели 2 утврђено је да наставници сматрају да је додатна настава потребна како би се код ученика подстицала даровитост (31,7\% наставника се слаже; 61,5\% наставника се у потпуности слаже). Својим неслагањем са тврдњом Додатна настава није неопходна у раду са даровитим ученицима, јер се њихова даровитост успешно може подстицати у редовној настави наставници су показали позитиван став према улози додатне наставе у раду са даровитима (24\% са одговором уопште се не слажем; 47,1\% са одговором не слажем се). Наставници сматрају да додатна настава даровитим ученицима пружа знања и развија способности које није могуће стећи у редовној настави (50\% наставника се слаже; 29,8\% наставника се потпуно слаже); да доприноси сузбијању досаде и незаинтересованости које могу да се јаве код даровитих ученика у редовној настави (42,3\% наставника се слаже; 21,2\% наставника се потпуно слаже); да даровитим ученицима пружа могућност да испоље склоности и способности и да развијају своју даровитост (53,8\% наставника се слаже; $21,2 \%$ наставника се у потпуности слаже). Осим тога, наставници сматрају да се у додатној настави могу задовољити потребе и интересовања даровитих ученика, што није могуће у редовној настави $(54,8 \%$ наставника се слаже; $16,3 \%$ наставника се у потпуности слаже), као и да даровитост није довољно подстицати само кроз додатну наставу (55,8\% наставника се слаже; 28,8\% наставника се у потпуности слаже). Подељеност у одговорима наставника присутна је код тврдњи: Припрема ученика за такмичење је најважнији задатак додатне наставе (највећи број наставника се нити слаже, нити не слаже (39,4\%), а слаже се $29,8 \%$ ); 3 а подстииање даровитости, уместо додатне наставе, боље је примењивати акиелерацију или груписање ученика према способностима (48,1\% наставника дало је одговор нити се слажем, нити се не слажем, а потом следе они који се слажу (30,8\%); Потенцијал даровитих ученика се може испољити тек у додатној настави (одговор нити се слажем нити се не слажем дало је 35,6\% наставника, а потом следе наставници који су дали одговор не слажем се $(29,8 \%))$.

Неодлучност наставника која се појављује у вези са наведеним тврдњама, сасвим је оправдана с обзиром на то да искуства које пружају акцелерација и груписање ученика по способностима нису у великој мери доступна у нашој земљи, као и због тога што је сваки даровити ученик индивидуа за себе, те није могуће донети генерални закључак о погодности једног, односно другог облика рада. Када је реч о улози додатне наставе у припреми ученика за такмичења, ставови наставника и у овом случају осликавају праксу која карактерише наш образовни систем, односно став да је једина улога додатне наставе припрема ученика за такмичења. Без обзира на то, можемо закључити да су ставови наставника у погледу улоге додатне наставе у подстицању даровитости код ученика позитивни, односно они су препознали њен значај и неопходност за рад са даровитима. 
Табела 3. Разлике у перцепцијама улоге додатне наставе у раду са даровитим ученицима из угла наставника с обзиром на варијаблу школа

\begin{tabular}{|c|c|c|c|c|c|c|}
\hline & Школа & M & SD & t-test & df & $\mathrm{p}$ \\
\hline \multirow{2}{*}{$\begin{array}{l}\text { Припрема ученика за такмичење је } \\
\text { најважнији задатак додатне наставе }\end{array}$} & Основна & 3,478 & 1,069 & \multirow{2}{*}{2,193} & \multirow{2}{*}{85,740} & \multirow{2}{*}{0,031} \\
\hline & Средња & 3,052 & 0,867 & & & \\
\hline \multirow{2}{*}{$\begin{array}{l}\text { Додатна настава доприноси сузбијењу досаде и } \\
\text { незаинтересованости које могу да се } \\
\text { јаве код даровитих ученика у редовној настави }\end{array}$} & Основна & 3,956 & 0,815 & \multirow{2}{*}{2,455} & \multirow{2}{*}{101,780} & \multirow{2}{*}{0,016} \\
\hline & Средња & 3,500 & 1,080 & & & \\
\hline \multirow{2}{*}{$\begin{array}{l}\text { За подстицање даровитости, уместо додатне } \\
\text { наставе, боље је примењивати акцелерацију } \\
\text { или груписање ученика према способностима }\end{array}$} & Основна & 3,413 & 0,858 & \multirow{2}{*}{2,209} & \multirow{2}{*}{102} & \multirow{2}{*}{0,029} \\
\hline & Средња & 3,052 & 0,804 & & & \\
\hline
\end{tabular}

Статистички значајна разлика у ставовима наставника с обзиром на варијаблу школа утврђена је код тврдњи: Припрема ученика за такмичење је најважнијизадатак додатне наставе, с обзиром на то да је $\mathrm{p}=0,031 ; \mathrm{p}<0,05$; Додатна настава доприноси сузбијењу досаде и незаинтересованости које могу да се јаве код даровитих ученика у редовној настави, јер је p<0,05 ( За подстицање даровитости, уместо додатне наставе, боље је примењивати акцелераџију или груписање ученика према способностима, $\mathrm{p}=0,029$ ( $<00,05)$. И поред тога што је највећи број наставника показао неодлучност у вези са првом и трећом тврдњом, и слагање са другом тврдњом, добијене вредности нам говоре да се ставови наставника разликују у зависности од школе у којој предају (основна, односно средња школа). У сва три случаја статистички значајна разлика условљена је чешћим истицањем потврдних одговора од стране наставника основних школа. Како је период основношколског образовања период најинтензивнијег психо-физичког развоја који карактерише и потреба за доказивањем и самопотврђивањем ученика, могу се разумети резултати у подручју припремања за такмичење као најважнијег задатка додатне наставе.

Табела 4. Разлике у перцепцијама улоге додатне наставе у раду са даровитим ученицима из угла наставника с обзиром на варијаблу научна област

\begin{tabular}{lcccccc}
\hline & Научна област & $\mathrm{M}$ & $\mathrm{SD}$ & $\mathrm{t}$-test & $\mathrm{df}$ & $\mathrm{p}$ \\
\hline $\begin{array}{l}\text { Припрема ученика за } \\
\begin{array}{l}\text { такмичење је најважнији } \\
\text { задатак додатне наставе }\end{array}\end{array} \begin{array}{c}\text { Природне науке } \\
\text { Друштвене } \\
\text { науке }\end{array}$ & 2,856 & 0,914 & & & \\
\hline
\end{tabular}

Статистички значајна разлика у ставовима наставника појављује се код тврдње Припрема ученика за такмичење је најважнији задатак додатне наставе $(\mathrm{p}=0,001, \mathrm{p}<0,05)$. Иако смо већ утврдили да наставници без обзира на варијабле у највећем броју случајева показују слагање са наведеном тврдњом, 
разлике у одговорима се јављају у зависности од тога да ли је реч о наставнику природних, односно наставнику друштвених наука. Утврђене резултате делимично можемо приписати податку да су такмичења из области природних наука у нашој земљи заступљенија, те су ови наставници упућенији на остваривање ове функције додатне наставе.

\section{2. Улога додатне наставе у раду са даровитим ученицима из угла родитеља}

Осим наставника, желели смо да дођемо и до ставова родитеља о додатној настави. Одговоре родитеља на питање: Како видите улогу додатне наставе у раду са даровитим ученицима? можемо поделити у три категорије:

1. Родитељи који сматрају да додатне наставе нема довољно (,Мислим да је јако важна и да би могло да је има више, али то захтева посебну припрему и рад, па је неопходно да буде плаћена. У овим условима, наставници дају пуно “; „,Не одржава се тј. само на иницијативу детета “; „Додатне наставе нема довољно “);

2. Родитељи који сматрају да је главна (и једина) сврха додатне наставе припрема ученика за такмичења (,ККао добар вид припреме за такмичење“; „,Довољно подиже самопоуздање детету за учешће на такмичењима“; „Додатна настава треба да буде иентрални део активности које се одвијају преко редовних обавеза (суштина припрема за такмичења и нова сазнања) ");

3. Родитељи који подржавају додатну наставу као изузетно значајан облик рада са даровитим ученциима (,Додатна настава омогућава да даровити ученици прошире и употпуне своја знања“; „Проширује знање и даје одговоре на она питања која не могу да се обраде на редовним часовима“; ,Као подрику; развој самопоуздања; подстииање истраживачког духа... ").

Уколико одговоре родитеља сагледамо у односу на варијаблу ниво образовања, долазимо до закључка да већина родитеља који изражавају позитиван став према улози и вредности додатне наставе припадају категорији родитеља највишег образовног статуса. Родитељи сматрају да је додатна настава веома корисна у подстицању даровитости њихове деце, проширивању и продубљивању њихових знања и усмеравању и неговању њихових потенцијала. Позитивни ставови родитеља представљају значајну основу за оставривање успешне сарадње школе и породице у подстицању и развију даровитости, што правилном педагошком интевенцијом треба искористити и ставити у функцију обезбеђивања квалитета и ефикасности рада са даровитима.

\section{Закључак}

Школа садржи богатство потенцијала за задовољавање специфичних потреба свих ученика. Многобројне наставне и ваннаставне активности стоје на располагању онима који желе да њихове могућности искористе на најбољи мо- 
гући начин, за развој како оних просечних, тако и оних ученика који се налазе испод или изнад просека. У фокусу нашег истраживања налази се улога додатне наставе у раду са даровитим ученицима.

На основу спроведеног истраживања, можемо закључити да и наставници и родитељи препознају додатну наставу као значајан облик рада са даровитим ученицима, увићају њену улогу у подржавању даровитости и подстицању њеног даљег развоја, приликом чега је важно нагласити да додатна настава, према мишљењу родитеља, није заступљена у довољној мери. Поред тога, наставници сматрају да се даровитост не може подстицати само путем додатне наставе већ је треба комбиновати са другим облицима и начинима подстацања индиивидуалних капацитета ученика.

И поред тога што добијене резултате можемо означити као позитивне, не смемо заборавити на проблеме који прате даровите ученике у школској средини, пре свега у самој идентификацији даровитих, а потом и у њиховом адекватном третману, јер није довољно да се додатна настава реализују да бисмо закључили да се даровитост ученика заиста и подстиче. Нагласак је и увек мора бити на квалитету подршке и облика рада са њима, никако на њиховом квантитету. Уз то, систем подршке даровитим ученицима у школи мора бити заснован на сарадњи наставника, стручних служби, родитеља и самих даровитих ученика.

\section{Литература}

Adžić, D. (2011). Darovitost i rad s darovitim učenicima, kako teoriju prenijeti u praksu. Život i škola, 25 (57), 171-184.

Bakovljev, M. (1998). Didaktika. Beograd: Naučna knjiga.

Đorđević, J. (1981). Savremena nastava: organizacija i oblici. Beograd: Naučna knjiga.

Hebib, E. i Spasenović, V. (2011). Značaj razgranate strukture školskih aktivnosti. Nastava $i$ vaspitanje, 60 (1), 65-80.

Janković, P. i Rodić, R. (2007). Školska pedagogija. Sombor: Pedagoški fakultet.

Karijašević, L. (2013). Izazovi učitelja u radu sa darovitom decom. Metodički obzori, $8(1), 71-84$.

Lazarević, V. (2005). Individualizovana nastava. Obrazovna tehnologija, 2, 47-60.

Marković, M. (2005). Individualizovana nastava. Obrazovna tehnologija, 2, 61-66.

Milinković, N. (2014). Didaktičke vrednosti diferencirane nastave u radu sa učenicima potencijalno darovitim za matematiku. U R. Nikolić (ur.), Nastava i učenje: savremeni pristupi i perspektive (str. 569-580). Užice: Učiteljski fakultet.

Miljanović, T. i Topić, M. (2010). Efikasnost realizacije dodatne nastave iz biologije u osnovnoj školi. Nastava $i$ vaspitanje, 59(3), 401-411.

Muratović, L. N. i Musić, M. M. (2017). Oblici vaspitno-obrazovne podrške potencijalima darovitih učenika u razrednoj nastavi. Inovacije u nastavi, 20 (1), 96-107.

Stanojević, D. (2011). Savremenom nastavnom kulturom do altruističke orijentacije škole. Godišnjak Učiteljskog fakulteta u Vranju, (2), 61-74.

Vilotijević, M. (1999). Didaktika 1: predmet didaktike. Beograd: Naučna knjiga: Učiteljski fakultet. 
Vilotijević, M. i Vilotijević, N. (2016). Modeli razvijajuće nastave 1. Beograd: Učiteljski fakultet.

\title{
THE ROLE OF ADDITIONAL CLASSES IN SUPPORTING AND DEVELOPING GIFTEDNESS
}

\author{
Marija Jovanović, Tamara Vukić \\ University of Niš, Faculty of Philosophy in Niš, Department of Pedagogy
}

\begin{abstract}
School, with its rich offer of curricular and extracurricular activities provides the opportunity for the gifted students' development, by stimulating their potentials and abilities and by meeting their specific needs. In this paper we have presented the results obtained in the research aimed at determining how the teachers and the gifted students' parents perceive the role of additional classes in supporting students' giftedness. The results showed that most of the teachers and parents recognize the important role of the additional classes in providing individualization in the work with gifted students, despite the fact that there are teachers and parents who think that the only role of additional classes is to prepare gifted children for different competitions. In teachers' opinion, additional classes provide the knowledge and develope the skills which cannot be acquired in regular classes. They also provide the opportunity for students to satisfy their needs and interests and to manifest their individuality, and they contribute to the suppresion of boredom and lack of interest that can be found among the gifted students in regular classes. Despite the teachers' positive attitude on the importance and the role of additional classes in supporting the giftedness, they share the opinion that supporting the giftedness only through additional classes is not enough.
\end{abstract}

Key words: additional classes, giftedness, students, teachers, parents.

\section{Citiranje članka:}

Jovanović, M. i Vukić, T. (2018). Uloga dodatne nastave u podsticanju i razvoju darovitosti. Godišnjak za pedagogiju, 3(1), 7-18. 